\title{
ANALISIS PENGARUH FAKTOR - FAKTOR PEMBANGUN TRUST TERHADAP PARTISIPASI PENGGUNA PADA C2C E - COMMERCE STUDI KASUS : FORUM JUAL BELI KASKUS
}

\author{
Windarsyah, Hendrik, Teduh Dirgahayu \\ Program Magister Teknik Informatika, Fakultas Teknologi Industri, \\ Universitas Islam Indonesia, Jalan Kaliurang. Km.14,5. Sleman. Yogyakarta.
}

\begin{abstract}
$C 2 C$ (consume $r$-to -consumer) e-commerce is currently growing fast in Indonesia. A C2C ecommerce website provides a marketplace in which buyers and sellers meet and make commercial transactions. Such a transaction requires high trust from both parties, since marketplaces typically have no or less sufficient mechanisms to assure that a transaction is safe. This paper analyses whether several factors that build trust has influence on one's willingness to participate in a transaction in a $\mathrm{C} 2 \mathrm{C}$ e-commerce website. Factors that are considered are structural assurance, familiarity, perceived similarity, perceived reputation and perceived risk. Data are collected using a Likert-scaled questionanaire from 109 respondents i.e. The users of FJB (Forum Jual Beli, trading forum) Kaskus. Data are analysed using the SEM (Structural Equation Model) method. The results show that (i) perceived reputation has positive and significant influence on trust; and (ii) trust has positive and significant influence on participation.
\end{abstract}

Keywords: e-commerce, structural assurance, familiarity, perceived similarity, perceived reputation, perceived risk, trust, participation.

\section{PENDAHULUAN}

E-commerce merupakan kegiatan bisnis perdagangan (jual - beli) melalui internet yang dapat mengefektifkan dan mengefisiensikan penggunaan waktu. Pelaku bisnis dapat melakukan transaksi perdagangan dimana pun dan kapanpun selama ia terhubung ke internet. $E$ commerce melibatkan transaksi antara penjual dan pembeli, beserta proses internal didalamnya (Javalgi dan Ramsey, 2001). Semua transaksi perdagangan tersebut dilakukan tanpa memerlukan tatap muka antara pihak penjual dan pihak pembeli. Mereka melakukan transaksi perdagangan (jual beli) tersebut berdasarkan atas trust (rasa percaya) antara satu sama lain. Masing - masing pihak di tuntut kejelian dan kehati - hatiannya agar ia terhindar dari kemungkinan penipuan. Salah satu bentuk $e$ - commerce yang sedang marak di Indonesia adalah C2C (consumerto - consumer), misal : berniaga.com, tokobagus.com, bukalapak.com dan Forum Jual Beli Kaskus. C2C e - commerce lazimnya berupa situs layanan yang berlaku sebagai pasar di mana penjual dan pembeli bisa saling bertemu dan berinteraksi. Seorang konsumen (calon pembeli) dapat melihat dan mempelajari barang atau jasa yang ditawarkan oleh konsumen lain (penjual). Pada akhirnya, interaksi ini diharapkan dapat menghasilkan transaksi jual - beli antara penjual dan pembeli dengan difasilitasi oleh situs tersebut. $\mathrm{C} 2 \mathrm{C} e$ commerce memerlukan trust yang tinggi dari kedua belah pihak karena proses jual belinya tidak memiliki mekanisme untuk menjamin keamanan transaksi. Hal ini berbeda dengan B2C (business - to consumer) $e$-commerce di mana trust lebih banyak dibangun pada sisi pembeli. Pihak penjual, yang juga bertindak sebagai penyedia situs layanan, harus membangun trust pembeli dengan cara, antara lain, melengkapi situsnya dengan mekanisme mekanisme yang mampu menjamin keamanan transaksi. Salah satu situs $\mathrm{C} 2 \mathrm{C} e-$ commerce yang banyak diminati di Indonesia adalah Forum Jual Beli (FJB) Kaskus. Banyaknya transaksi yang terjadi di FJB Kaskus dapat mengundang tindak 
kejahatan seperti penipuan, pencurian data dan risiko - risiko kejahatan transaksi lain. Lemahnya atau ketiadaan mekanisme yang menjamin transaksi jual - beli pada $\mathrm{C} 2 \mathrm{C} e$ commerce secara umum menuntut trust yang tinggi antara pihak penjual dan pembeli. Jika trust sudah tercipta, maka partisipasi pengguna dalam bertransaksi diharapkan bisa ikut tercipta.

Dalam penelitian ini, dilakukan suatu analisis pengaruh faktor - faktor pembangun trust terhadap partisipasi pengguna FJB Kaskus. Dengan mengetahui pengaruh faktor - faktor tersebut, satu pihak dapat mengetahui kapan sebaiknya ia dapat mempercayai dan berpartisipasi dalam transaksi jual - beli dengan pihak lain, sehingga risiko kejahatan transaksi dapat diminimalkan. Pihak FJB Kaskus dapat menggunakan faktor - faktor tersebut sebagai pertimbangan dalam merancang strategi dan mekanisme keamanan transaksi di situsnya. Makalah ini disusun sebagai berikut. Bagian 2 melakukan tinjauan pustaka terhadap penelitian - penelitian sebelumnya. Bagian 3 menggambarkan metode penelitian yang dilakukan. Bagian 4 menyajikan hasil dan pembahasannya. Bagian 5 menutup makalah ini dengan kesimpulan dan saran penelitian lanjutan.

\section{TINJAUAN PUSTAKA}

\subsection{E-Commerce}

E - Commerce adalah aktivitas penjualan dan pembelian barang atau jasa melalui media internet yang dapat dilakukan oleh siapa saja dengan mitra bisnisnya, tanpa dibatasi ruang dan waktu. Aktivitas $e$ commerce sesungguhnya mengandung makna adanya hubungan antara penjual dan pembeli, transaksi antar pelaku bisnis dan proses internal yang mendukung transaksi dengan perusahaan (Javalgi dan Rmsey, 2001). Model transaksi bisnis dalam $e$ - commerce dapat berupa Business to Consumer (B2C), Business to Business (B2B), dan Consumer to Consumer (C2C).

Di Indonesia, transaksi langsung antar pelanggan $(\mathrm{C} 2 \mathrm{C})$ sedang marak saat ini seperti forum jual beli on - line. Dengan mengakses satu situs $e$ - commerce yang ada, satu konsumen dapat melihat barang ataupun jasa yang dijual oleh konsumen lain ataupun menjual barang dan jasanya kepada konsumen lain. Pada akhirnya proses transaksi akan muncul dari adanya transaksi bisnis singkat yang difasilitasi oleh situs $e$ commerce ini.

\subsection{Trust}

Dalam Jarvenpaa dan Tractinsky (1999), trust di sistem $e$ - commerce didefinisikan sebagai kesediaan seseorang terhadap tindakan pihak lain untuk melakukan transaksi, walaupun pihak lain tersebut dapat dengan mudah merugikan dirinya. Trust memainkan peran penting dalam mempengaruhi perilaku seseorang, sehingga orang tersebut akan bertindak lebih proaktif ketika ia mempercayai suatu komunitas atau orang lain. (Rothaermel dan Sugiyama, 2001 dalam Lu et al, 2010). Faktor - faktor pembangun trust, antara lain, adalah sebagai berikut :

Structural Assurance, Faktor ini mengacu pada penilaian terhadap regulasi, jaminan keamanan, dan aturan - aturan lainnya berjalan dengan baik dalam bertransaksi (McKnight et al., 1998). Dalam suatu komunitas, pengelolaan suatu komunitas akan mempunyai efek positif terhadap keterlibatannya dalam suatu transaksi oleh anggotanya. Menurut $\mathrm{Lu}$ et al (2010) jaminan privasi, prosedur dan jaminan keamanan yang diberikan oleh komunitas virtual akan meningkatkan trust dari para anggotanya. Selain itu, jika suatu situs web dalam mempertahankan prosedur dan mengelola komunitas virtual - nya dengan baik, maka anggotanya dapat memiliki keyakinan yang lebih baik dan memiliki trust terhadap situs web tersebut.

Familiarity, Menurut Lu et al (2010), familiarity dapat diterapkan untuk trust interpersonal, karena seseorang biasanya cenderung mempercayai orang lain yang telah mereka kenal. Familiarity terjadi saat seseorang berinteraksi dengan pihak lain dalam beberapa waktu dan mengakumulasi trust yang dihasilkan dari pengalaman - 
pengalaman berinteraksi dengan pihak lain tersebut. Oleh karena itu, ada pengaruh positif dari familiarity terhadap trust. Perceived Similarity Doney dan Canon (1997) menemukan bahwa trust antara pembeli dan penjual secara signifikan dipengaruhi oleh similarity, yakni trust dibangun berdasarkan karakteristik umum yang sama yang dimiliki oleh para anggota suatu komunitas. Ketika beberapa orang dikelompokkan bersama dalam suatu komunitas, maka mereka akan cenderung melihat satu sama lain dengan pandangan yang positif, sehingga dapat menimbulkan trust diantara mereka (McKnight et al., 1998 dalam Lu et al., 2010).

Perceived Reputation Reputation memberikan keyakinan kepada pihak lain mengenai kemampuan, integritas dan niat baik (goodwill). Keyakinan ini akan membantu meningkatkan trust terutama ketika pihak - pihak tersebut belum pernah berinteraksi sebelumnya sehingga belum memiliki pengetahuan tentang masing masing pihak (McKnight et al., 1998).

Perceived Risk Perceived risk dinilai sebagai tingkat persepsi konsumen akan hasil negatif yang mungkin didapatkannya dari suatu transaksi (Featherman dan Pavlou, 2002). Perceived risk berpengaruh secara negatif terhadap kerelaan untuk membeli suatu produk dalam situs $e$ - commerce (Jarvenpaa dan Tractinsky, 1999). Faktor ini memiliki dampak terhadap sikap dan tingkah laku seseorang dalam melakukan transaksi dengan pihak lain. Tingkat risiko yang tinggi akan membuat konsumen tidak nyaman dalam menggunakan situs $e$ - commerce bahkan melakukan transaksi jual beli.

\subsection{Partisipasi}

Partisipasi adalah keterlibatan seseorang dalam suatu kegiatan tertentu. Dalam konteks $e$ - commerce, tingkat partisipasi diukur dari banyaknya konsumen yang melakukan transaksi (Kim et al., 2003). Partisipasi sangat ditentukan oleh trust terhadap rekanan, media, atau lainnya yang terlibat dalam suatu kegiatan. Partisipasi dalam $e$ - commerce akan tumbuh dengan baik apabila pihak penjual mampu menjaga trust yang telah diberikan oleh para konsumennya. Ketika konsumen merasakan bahwa penjual telah menjaga dengan baik trust yang diberikan, maka konsumen dengan senang hati akan terus meningkatkan partisipasinya.

Bahkan dalam situasi tertentu, konsumen akan mengajak atau memberitahukan kepada orang lain untuk ikut berpartisipasi dalam kegiatan tersebut.

\subsection{Penelitian Sebelumnya}

Analisis faktor - faktor yang mempengaruhi trust pada komunitas virtual telah diteliti oleh ( $L u$ et al, 2010). Penelitian ini dilakukan pada mahasiswa sarjana dan pasca sarjana dari anggota komunitas virtual Taobao.com. Pengambilan data dilakukan dengan menyebarkan kuesioner. Alat analisis yang digunakan adalah Principal Component Factor (PCF). Hasil penelitian ini menunjukkan bahwa structural assurance, familiarity dan perceived similarity mempunyai pengaruh positif terhadap trust anggota terhadap komunitas virtual. Penelitian mengenai kaitan antara trust dan loyalitas pelanggan $e$ - commerce telah dilakukan oleh Jarvenpaa dan Tractinsky (1999). Penelitian ini dilakukan untuk mengetahui pengaruh faktor perceived reputation pada tingkat trust bertransaksi lintas budaya antara Australia dan Israel. Penelitian dilakukan dengan survey terhadap pembelian buku di situs amazon.com. Hasilnya menunjukkan bahwa tidak ada perbedaan signifikan antara Australia dan Israel karena memiliki budaya yang relatif sama.Penelitian mengenai faktor - faktor yang dapat mempengaruhi pembeli dalam pengambilan keputusan bertransaksi di $e$ - commerce pernah telah diteliti oleh Yang (2013). Penelitian ini dilakukan pada semua anggota komunitas virtual Taobao.com. Pengambilan data dilakukan dengan menyebarkan kuesioner. Alat analisis yang digunakan adalah VARIMAX Rotation. 
Hasil penelitian ini menunjukkan bahwa perceived risk berpengaruh dan signifikan terhadap trust dalam pengambilan keputusan bertransaksi di komunitas virtual Taobao.com. Penelitian mengenai trust mitra dagang dengan partisipasi dalam $e$ commerce pernah telah diteliti oleh Ratnasingham dan Kumar (2004). Penelitian ini dilakukan pada pengadopsi, implementator, manajer sistem informasi, pembeli, pemasok, penghasil produk, dan distributor yang terlibat dalam transaksi $e$ commerce. Alat pengumpulan data menggunakan kuesioner dengan alat ukur skala Likert. Alat analisis yang digunakan adalah Linear Structural Relationship (LISREL). Hasil yang diperoleh adalah trust mitra dagang meningkatkan partisipasi dalam $e$ - commerce.

\section{METODE PENELITIAN}

Penelitian ini dilakukan pada pengguna FJB Kaskus. Kerangka penelitian ini ditunjukkan pada Gambar 1. Dari kerangka penelitian tersebut, dapat dikembangkan hipotesis sebagai berikut :

H1 : Structural Assurance berpengaruh positif secara langsung terhadap trust pengguna.

H2 : Familiarity berpengaruh positif secara langsung terhadap trust pengguna.

H3 : Perceived Similarity berpengaruh positif secara langsung terhadap trust pengguna.

H4 : Perceived Reputation berpengaruh positif secara langsung terhadap trust pengguna.

H5 : Perceived Risk berpengaruh negatif secara langsung terhadap trust pengguna.

H6 : Structural Assurance berpengaruh positif secara langsung terhadap Participation pengguna.

H7 : Familiarity berpengaruh positif secara langsung terhadap Participation pengguna.

H8 : Perceived Similarity berpengaruh positif secara langsung terhadap Participation pengguna.
H9 : Perceived Reputation berpengaruh positif secara langsung terhadap Participation pengguna.

H10 : Perceived Risk berpengaruh negatif secara langsung terhadap Participation pengguna.

H11: Trust berpengaruh positif secara langsung terhadap Participation pengguna.

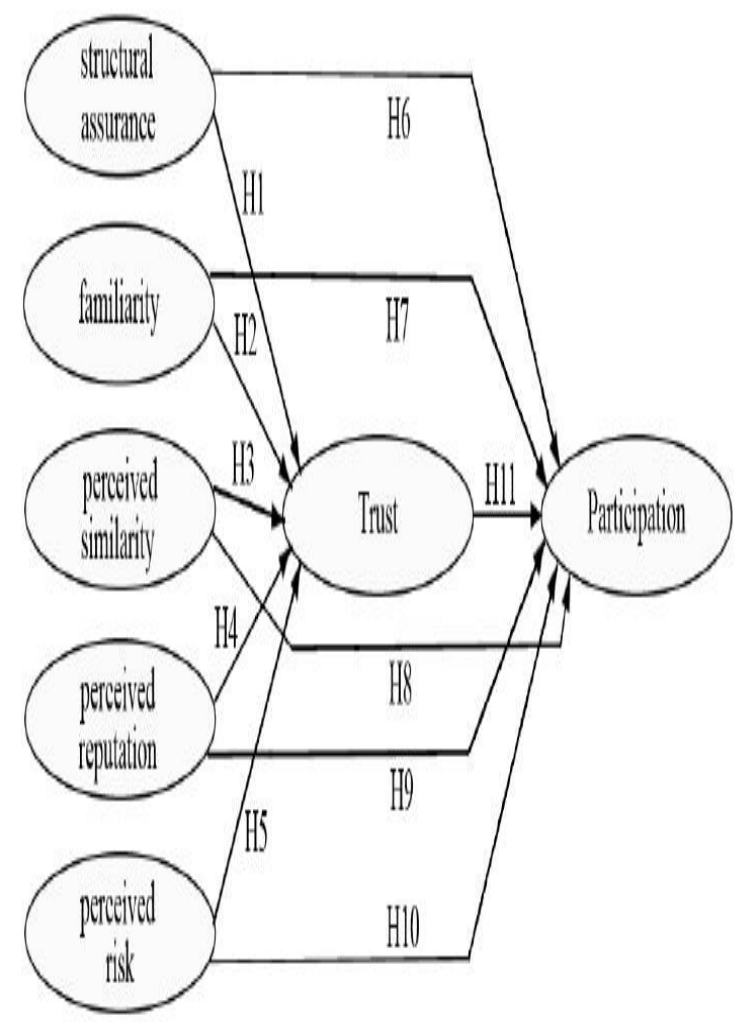

Gambar 1. Kerangka dan Hipotesis Penelitian.

Metode utama dalam penelitian ini adalah survey, yakni mengambil sampel dari populasi menggunakan kuisioner dengan menggunakan skala Likert sebagai alat pengumpulan data pokok. Populasi pada penelitian adalah pengguna yang telah menjadi anggota dan pernah melakukan transaksi di FJB Kaskus. Prosedur pengumpulan data dilakukan dengan membuat sebuah posting (thread) di Kaskus yang isinya merujuk ke halaman situs kuesioner on-line melalui link http://kwiksurveys.com/s.asp? sid=tdvx7cp69 Olay7e147297. 
Pertanyaan - pertanyaan yang diajukan memiliki indikator dalam mengukur masing masing variabel, indikator tersebut juga mewakili dari masing - masing pertanyaan, seperti structural assurance tentang jaminan keamanan dan pengelolaan situs komunitas virtual - nya, familiarity tentang interaksi dan keakraban dari para anggota, perceived similarity tentang kesamaan karakteristik dan kesamaan persepi anggotanya dalam bertransaksi, perceived reputation tentang reputasi dan memberikan keyakinan pada setiap anggota, perceived risk tentang resiko penipuan resiko privasi dalam bertransaksi, trust tentang percaya pada situs dan anggota komunitas virtual, dan participation tentang melakukan transaksi kembali dan merekomendasikan kepada anggota lain. Analisis data dilakukan dengan menggunakan metode Structural Equation Model (SEM), untuk analisis deskriptif menggunakan perangkat lunak AMOS.

\section{HASIL DAN PEMBAHASAN}

Diagram alur hubungan kausalitas antar konstruksi beserta indikatornya diperlihatkan pada Gambar 2.

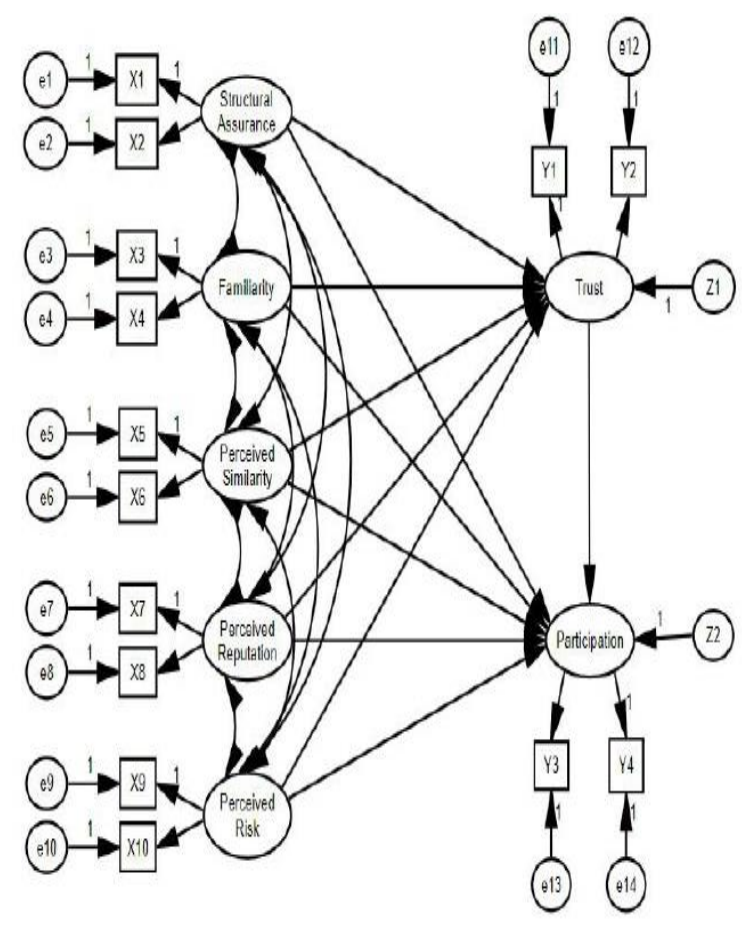

Gambar 2. Model Diagram Alur Hubungan Kausalitas.
Diagram tersebut terdiri dari 7 konstruksi yaitu structural assurance, familiarity, perceived similarity, perceived reputation, perceived risk, trust, dan participation. 14 indikator pertanyaan dari masing - masing variabel yaitu X1, X2, X3, X4, X5, X6, X7, $\mathrm{X} 8, \mathrm{X} 9, \mathrm{X} 10, \mathrm{Y} 1, \mathrm{Y} 2, \mathrm{Y} 3$ dan Y4

\subsection{Uji Validitas}

Validas diuji melalui Analisis Faktor Konfirmatori. Jika loading factor dari indikator > 0.30 indikator tersebut valid (Ghozali, 2008). Dari hasil pengujian validitas, nilai loading factor semua indikator tidak ada yang lebih kecil dari 0,30. Dengan demikian, semua indikator dinyatakan valid dan proses evaluasi model dapat dilanjutkan.

\subsection{Uji Reliabilitas}

Berdasarkan hasil uji reliabilitas, nilai total dari semua construct reliability - nya adalah 0,76 , yang berada di atas syarat minimal $(0,6)$. Dengan demikian, semua konstruksi dalam penelitian ini layak untuk digunakan dalam model.

\subsection{Evaluasi Indeks Kriteria Goodness of Fit}

Goodness of fit merupakan tujuan utama dalam SEM, yaitu ingin mengetahui sampai seberapa jauh model yang dihipotesiskan 'fit' atau cocok dengan sampel data. Dari hasil perhitungan tersebut, hampir dari semua perhitungan indeksnya good fit, hal ini berarti model yang dihipotesiskan telah cocok dengan data observasi. Hasilkan indeks goodness of fit sebagaimana ditunjukkan tabel 1. 
Tabel 1. Hasil Perhitungan

Indeks Goodness of Fit.

\begin{tabular}{|c|c|c|c|}
\hline $\begin{array}{c}\text { Goodness of } \\
\text { Fit Index }\end{array}$ & $\begin{array}{c}\text { Hasil } \\
\text { model }\end{array}$ & $\begin{array}{c}\text { Cut-Off- } \\
\text { Value }\end{array}$ & Ket \\
\hline $\begin{array}{c}\text { X2 - Chi }- \\
\text { Square }\end{array}$ & 69,237 & $\begin{array}{c}\text { Diharapkan } \\
\text { kecil }\end{array}$ & Good fit \\
$\begin{array}{c}\text { Significane } \\
\text { Probability }\end{array}$ & 0,011 & $\geq 0,05$ & Good fit \\
RMSEA & 0,047 & $\leq 0,08$ & Good fit \\
GFI & 0,922 & $\geq 0,90$ & Good fit \\
CMIN/DF & 1,236 & $\leq 2,00$ & Good fit \\
TLI & 0,957 & $\geq 0,95$ & Good fit \\
CFI & 0,974 & $\geq 0,95$ & Good fit \\
\hline
\end{tabular}

\subsection{Uji Hipotesis}

Hipotesis H1 : Structural assurance berpengaruh positif secara langsung terhadap trust pengguna. Berdasarkan hasil pengujian diketahui bahwa variabel structural assurance mempunyai pengaruh positif secara langsung terhadap variabel trust sebesar 0,061 dengan nilai p-value 0,702 . Pada taraf keyakinan 0,05 yang berarti pengaruh variabel tersebut tidak signifikan. Hal ini mungkin disebabkan karena pengguna FJB Kaskus masih meragukan sistem keamanan jaringan sehingga menimbulkan rasa was - was dalam melakukan suatu transaksi. Apalagi pengelolaan dari oleh administrator FJB Kaskus yang terkadang lamban dalam pengecekkan atau menyaring posting (thread) baru yang ada di FJB Kaskus tersebut.

Hipotesis H2 : Familiarity berpengaruh positif secara langsung terhadap trust pengguna. Hasil pengujian menunjukkan bahwa variabel familiarity memiliki pengaruh positif secara langsung terhadap variabel trust sebesar 0,042 dengan nilai $p$ value 0,602 pada taraf keyakinan 0,05 atau pengaruh tersebut tidak signifikan. Hal ini mungkin disebabkan oleh sifat dari para pengguna FJB Kaskus yang memiliki sifat individu dan lebih percaya diri dalam mengambil keputusan, dengan adanya kultur dan filosofi dalam berinteraksi, sehingga interaksi yang terjadi dalam FJB Kaskus belum tentu dapat menimbulkan trust dalam bertransaksi.

Hipotesis H3 : Perceived similarity berpengaruh positif secara langsung terhadap trust pengguna. Hasil pengujian menunjukkan bahwa variabel perceived similarity memiliki pengaruh positif secara langsung terhadap variabel trust sebesar 0,110 dengan nilai $p$-value 0,827 pada taraf keyakinan 0,05 atau pengaruh tersebut tidak signifikan. Hal ini mungkin disebabkan oleh karakteristik responden yang berbeda - beda. Meskipun ada beberapa persepsi yang sama dengan pengguna yang lain, bukan berarti pengguna FJB Kaskus percaya begitu saja terhadap pengguna lain.

Hipotesis H4 : Perceived reputation berpengaruh positif secara langsung terhadap trust pengguna. Hasil pengujian menunjukkan bahwa variabel perceived reputation memiliki pengaruh positif secara langsung terhadap variabel trust sebesar 0.006 dengan nilai p-value 0.001 pada taraf keyakinan 0,05 atau pengaruh tersebut signifikan. Temuan ini menunjukkan bahwa informasi profil pengguna FJB Kaskus yang memiliki reputasi baik akan juga dengan kesaksian pengguna lain tentang pengalaman bertransaksi terhadap pihak terkait merupakan satu cara pihak tersebut dalam mempersepsikan bahwa dirinya memiliki reputasi yang baik.

Hipotesis H5 : Perceived risk berpengaruh negatif secara langsung terhadap trust pengguna. Hasil pengujian menunjukkan bahwa variabel perceived risk memiliki pengaruh positif secara langsung terhadap variabel trust sebesar 0,561 dengan nilai $p$-value 0,973 pada taraf keyakinan 0,05 atau pengaruh tersebut tidak signifikan. Hal ini mungkin disebabkan oleh pengguna FJB Kaskus cenderung lebih berhati - hati dalam menilai suatu transaksi untuk mengambil keputusan bertransaksi sehingga resiko terburuk dapat diminimalkan. 
Hipotesis H6 : Structural assurance berpengaruh positif secara langsung terhadap participation pengguna. Hasil pengujian menunjukkan bahwa variabel structural assurance memiliki pengaruh positif secara langsung terhadap variabel participation sebesar 0,705 dengan nilai $p$ value 0,658 ; pengaruh tidak langsung sebesar 0,043; dan pengaruh total sebesar 0,040. Pada taraf keyakinan 0,05, pengaruh tersebut tidak signifikan. Hal ini mungkin disebabkan lambannya pengelolaan administrator dalam mengecek atau menyaring thread - thread baru yang ada di FJB Kaskus sehingga membuat pengguna rentan mengalami tindak penipuan. Oleh karena itu, pengguna FJB Kaskus merasa khawatir dalam melakukan transaksi apabila menemukan suatu thread baru.

Hipotesis H7 : Familiarity berpengaruh positif secara langsung terhadap participation pengguna. Hasil pengujian menunjukkan bahwa variabel familiarity ternyata memiliki pengaruh negatif secara langsung terhadap variabel participation sebesar 0,014 dengan nilai $p$-value 0,693 ; pengaruh tidak langsung sebesar 0,029; dan pengaruh total sebesar 0,016. Pada taraf keyakinan 0,05 , pengaruh tersebut tidak signifikan. Temuan ini menunjukkan bahwa anggota FJB Kaskus bisa dikatakan lebih percaya diri dalam menentukan keputusannya dalam bertransaksi. Keakraban yang terjadi dalam FJB Kaskus belum tentu akan mendorong seseorang melakukan transaksi kembali dengan pengguna yang sama atau sekedar merekomendasikan pengguna tersebut kepada pengguna lain untuk ikut berpartisipasi.

Hipotesis H8 : Perceived similarity berpengaruh positif secara langsung terhadap participation pengguna. Hasil pengujian menunjukkan bahwa variabel perceived similarity memiliki pengaruh negatif secara langsung terhadap variabel participation sebesar -0,049 dengan nilai $p$ value 0,822 ; pengaruh tidak langsung sebesar 0,078; dan pengaruh total sebesar 0,029 .
Pada taraf keyakinan 0,05 , pengaruh tersebut tidak signifikan. Temuan ini menunjukkan bahwa pengguna yang memiliki kesamaan demografis dan tujuan yang sama dengan pengguna lain belum tentu akan mendorong kedua pengguna tersebut melakukan transaksi kembali di FJB Kaskus.

Hipotesis H9 : Perceived reputation berpengaruh positif secara langsung terhadap participation pengguna. Hasil pengujian menunjukkan bahwa variable perceived reputation memiliki pengaruh positif secara langsung terhadap variabel participation sebesar 0,073 dengan nilai $p$ value 0,594 ; pengaruh tidak langsung sebesar 0,004; dan pengaruh total sebesar 0,078. Pada taraf keyakinan 0,05, pengaruh tersebut tidak signifikan. Hal ini berarti seseorang bisa saja mempercayai reputasi salah satu pengguna FJB Kaskus, namun bukan berarti orang tersebut akan melakukan transaksi kembali dengan pengguna yang sama atau merekomendasikannya kepada anggota lain.

Hipotesis H10 : Perceived risk berpengaruh negatif secara langsung terhadap participation pengguna FJB Kaskus. Hasil pengujian menunjukkan bahwa variabel perceived risk memiliki pengaruh positif secara langsung terhadap variabel participation sebesar 0,085 dengan nilai $p$-value 0,870 ; pengaruh tidak langsung sebesar 0,396; dan pengaruh total sebesar 0,480 . Pada taraf keyakinan 0,05 , pengaruh tersebut tidak signifikan. Temuan ini berarti pengguna FJB Kaskus menganggap perceived risk menjadi variabel yang penting untuk dipertimbangkan sehingga pengguna lebih berhati - hati dalam melakukan transaksi. Oleh sebab itu, ketika seorang pengguna mendapati thread yang tidak sesuai dengan harapannya untuk dipercaya maka pengguna tersebut merasa enggan untuk memberikan komentar pada thread tersebut apalagi merekomendasikannya kepada pengguna lain. 
Hipotesis H11 : Trust berpengaruh positif secara langsung terhadap participation pengguna. Hasil pengujian menunjukkan bahwa variabel trust memiliki pengaruh positif secara langsung terhadap variabel participation sebesar 0,705 dengan nilai $p$-value $(0,000)$. Pada taraf keyakinan 0,05 , pengaruh tersebut signifikan. Jadi hal tersebut dapat memberikan semangat yang lebih positif bagi pengguna FJB Kaskus dalam melakukan transaksi kembali dan kemungkinan besar akan merekomendasikannya kepada pengguna lainnya untuk tidak khawatir (merasa berisiko) dalam melakukan transaksi melalui FJB Kaskus. Trust terbukti dapat meningkatkan participation pengguna di FJB Kaskus.Keseluruhan hasil uji hipotesis diatas dirangkum dalam Tabel 2.

Tabel2. Hasil Pengujian Hipotesis.

\begin{tabular}{|c|c|c|c|}
\hline $\mathrm{H}$ & Variabel 1 & Variabel 2 & Keterangan \\
\hline H1 & $\begin{array}{l}\text { Structural } \\
\text { Assurance }\end{array}$ & Trust & $\begin{array}{c}\text { Tidak } \\
\text { Signifikan }\end{array}$ \\
\hline $\mathrm{H} 2$ & Familiarity & Trust & $\begin{array}{c}\text { Tidak } \\
\text { Signifikan }\end{array}$ \\
\hline H3 & $\begin{array}{l}\text { Perceived } \\
\text { Similarity }\end{array}$ & Trust & $\begin{array}{c}\text { Tidak } \\
\text { Signifikan }\end{array}$ \\
\hline H4 & $\begin{array}{l}\text { Perceived } \\
\text { Reputation }\end{array}$ & Trust & $\begin{array}{c}\text { Tidak } \\
\text { Signifikan }\end{array}$ \\
\hline H5 & $\begin{array}{l}\text { Perceived } \\
\text { Risk }\end{array}$ & Trust & $\begin{array}{c}\text { Tidak } \\
\text { Signifikan }\end{array}$ \\
\hline H6 & $\begin{array}{l}\text { Structural } \\
\text { Assurance }\end{array}$ & Participation & $\begin{array}{c}\text { Tidak } \\
\text { Signifikan }\end{array}$ \\
\hline H7 & Familiarity & Participation & $\begin{array}{c}\text { Tidak } \\
\text { Signifikan }\end{array}$ \\
\hline H8 & $\begin{array}{l}\text { Perceived } \\
\text { Similarity }\end{array}$ & Participation & $\begin{array}{c}\text { Tidak } \\
\text { Signifikan }\end{array}$ \\
\hline H9 & $\begin{array}{l}\text { Perceived } \\
\text { Reputation }\end{array}$ & Participation & $\begin{array}{c}\text { Tidak } \\
\text { Signifikan }\end{array}$ \\
\hline $\mathrm{H} 10$ & $\begin{array}{l}\text { Perceived } \\
\text { Risk }\end{array}$ & Participation & $\begin{array}{c}\text { Tidak } \\
\text { Signifikan }\end{array}$ \\
\hline H11 & Trust & Participation & Signifikan \\
\hline
\end{tabular}


DAFTAR PUSTAKA

Doney, P.M., dan Cannon, J. P., (1997). An Examination of the Nature of Trust in Buyer - Seller Relationships. Journal of Marketing, 61 (2): 35-51.

Featherman dan Pavlou, (2002), Predicting E-Service Adoption: A Perceive Risk Facets Perspective, Eight America Conference on Information System.

Ghozali, I., (2008). Model Persamaan Struktural Konsep dan Aplikasi dengan Program AMOS 16.0. BP Universitas Diponegoro, Semarang.

Kim, D. J., Lee, K. Y., Lee, D., Ferrin, D. L., dan Rao, H. R., (2003). Trust, Risk and Benefit in Electronic Commerce : What Are The Relationships?, Proceedings of Ninth Americas Conference on Information Systems, pp. 168-174.

Lu. Y., Zhao, L. dan Wang, B. (2010). Online Social Networks to C2C ECommerce? Trust in Virtual Communities and its Effect on Consumers' Purchase Intention. Electronic Commerce Research and Applications. 9 (4): 346-360.

McKnight D.H, L.L Cummings dan N.L Chervany, (1998), Initial Trust formation in New Organizational relationship, Academy of Management Review, 23 (3): 473-490.

Mukherjee, A., dan Nath, P., (2003). A Model of Trust in Online Relationship Banking, International Journal of Bank Marketing, 21 (1): 515.

Rothaermel, F. T., dan Sugiyama, S., (2001). Virtual Internet Communities and Commercial Success : Individual and Community - Level Theory Grounded in the Atypical Case of TimeZone.Com. Journal of Management, 27 (3): 297-312.

Jarvenpaa, S.L., dan Tractinsky, N., (1999), Consumers Trust in an Internet Store, Information Technology and Management, 5(2): 1-35.
Javalgi, R. dan Ramsey, R., (2001). Strategic Issues of E-Commerce as an Alternative Global Distribustion System, International Marketing Review, 18 (4): 376-391.

Yang, Y., (2013). A Trust Mechanism on Decision - Making of Online Buyers on C2C Marketplaces. International Journal of E-Business Development. 3 (1) : 43-47. 